\title{
CZŁOWIEK W PRZESTRZENI TURYSTYCZNEJ
}

\section{Wstęp}

Przestrzeń turystyczna to struktura, którą tworzą elementy dziedzictwa przyrodniczego, antropogenicznego, infrastruktura oraz człowiek. Mówiąc o niej nie można pomijać człowieka, który będąc turystą-gościem stanowi jej istotę i staje się jej podmiotem, a zarazem przedmiotem podejmowanych badań. Zgodnie z przyjętymi założeniami, to właśnie człowiek-turysta jest podstawowym czynnikiem determinującym jej występowanie. Także człowiek (niekoniecznie turysta) wpływa na jej charakter, decyduje o jej rozwoju lub zaniku.

Człowiek jako podmiot przestrzeni turystycznej czy, szerzej, turystyki był i jest obiektem zainteresowań wielu dyscyplin naukowych. Wśród dostępnych na polskim rynku wydawniczym publikacji z zakresu socjologii na szczególną uwagę zasługują prace K. PRZECŁAWSKIEGO (2001), K. PODEMSKIEGO (2004), a także polskie przekłady opracowań angielskojęzycznych D. MACCANNELLA (2002) i J. URRY'EGO (2007). Z opracowań nietłumaczonych na język polski wymienić należy E. COHENA $(1972,1984)$, J. JAFARI'EGO (1989) CZY J. URRY'EGO i J. LARSENA (2011), M. HALLA i S. PAGE'A (2014). Zagadnienia te bywają często rozpatrywane $\mathrm{z}$ punktu widzenia konkretnych przestrzeni turystycznych: np. Taj Mahal (EDENSOR 2009), basen Morza Śródziemnego (BOISSEVAIN, red. 1996) czy Lubelszczyzny (m.in. BEDNAREK-SZCZEPAŃSKA 2010). Opracowania w większości zajmują się człowiekiem jako turystą (jego potrzebami, oczekiwaniami) oraz relacjami zachodzącymi 
między nim a gospodarzami (najczęściej mieszkańcami odwiedzanych przestrzeni), znacznie mniej miejsca poświęcając innym „aktorom" przestrzeni turystycznej - przedsiębiorcom, samorządom, organizacjom czy pracownikom branży turystycznej. Liczne typologie turystów, jako ważnych aktorów przestrzeni turystycznej (m.in. PRZECŁAWSKI 2001, COHEN 1972), na stałe zagościły w literaturze specjalistycznej z zakresu turystyki.

Jedną z nowszych publikacji na polskim rynku wydawniczym, podejmujących problematykę zachowań człowieka w kontekście jego zachowań turystycznych, jest Psychologia turystyki R. WINIARSKIEGO i J. ZDEBSKIEGO (2008). W podręczniku omówione zostały m.in. geneza, rozwój i motywacje aktywności turystycznej, relacje interkulturowe w turystyce zarówno w kontekście jednostki (turysty), jak i grupy turystycznej (WINIARSKI, ZDEBSKI 2008).

Człowiek w przestrzeni turystycznej jest także przedmiotem badań geografów turyzmu, czego dowodem są bardzo liczne opracowania dotyczące ruchu turystycznego, w których zazwyczaj omawiane są obok zagadnień ilościowych także kierunki wyjazdów, motywy i cele podejmowanych wyjazdów, rzadziej ich efekty (wpływ na odwiedzaną przestrzeń). Poza rolą turysty geografowie rzadziej dostrzegają role innych "aktorów" przestrzeni turystycznej. Jednym $\mathrm{z}$ najnowszych opracowań $\mathrm{w}$ tym zakresie jest praca R. PAWLUSIŃSKIEGO (2005), dotycząca wpływu samorządu lokalnego na rozwój przestrzeni turystycznej (przykład gmin Wyżyny Krakowsko-Częstochowskiej). W sferze zainteresowań geografów znajdują się także zagadnienia indywidualnej przestrzeni turystycznej użytkowanej przez jednostki czy grupy społeczne (LATOSIŃSKA 1998, KOWALCZYK-ANIOŁ 2007).

Problematyka różnych grup interesów działających w przestrzeni turystycznej nieobca jest także naukom ekonomicznym. Jednak badacze wywodzący się z tej dyscypliny naukowej koncentrują się głównie na efektach ekonomicznych działalności podmiotów gospodarczych, organizacji i władz $\mathrm{w}$ tej przestrzeni (m.in. KONIECZNA-DOMAŃSKA 1999, RAPACZ, red. 2001, GOŁEMBSKI, red. 2002, MEYER 2004). W opracowaniach tych turysta traktowany jest zazwyczaj jedynie jako źródło popytu turystycznego.

\section{Przestrzeń turystyczna jako scena}

To że przestrzeń można potraktować jako swego rodzaju scenę, na której różne role odgrywają różne podmioty nie jest niczym odkrywczym. Zagadnienia te zostały szeroko omówione $\mathrm{w}$ opracowaniach licznych autorów, 
wśród których można wymienić m.in. G.H. MEADA (1975), E. GOFFMANA (1981), I. SAGAN (2000) czy B. JAŁOWIECKIEGO (2010). O potrzebie „gry", często $\mathrm{w}$ wymyślonych, nierzeczywistych przestrzeniach i realiach świadczy stale rosnąca popularność gier typu RPG (ang. role-playing game) z zaplanowanym wcześniej scenariuszem, czy LARP (ang.live action role-playing), gdzie większość reguł tworzona jest w trakcie gry, w których zastosowana metafora życie-scena jest czymś oczywistym (SURDYK-ĆWIKLIŃSKA, SURDYK 2012).

Przestrzeń jako przedmiot badań licznych dyscyplin naukowych może być traktowana dwojako. Po pierwsze w ujęciu dosłownym w kontekstach zaproponowanych przez B. JAŁOWIECKIEGO (2010) (rys. 1), lub ujęciu metaforycznym, np. jako scena, na której zachodzą różnego rodzaju relacje między tą przestrzenią a grupami aktorów odgrywających na niej różne role (GOFFMAN 1981, MACCANNELL 2002) i wchodzących także w relacje między sobą (rys. 4).

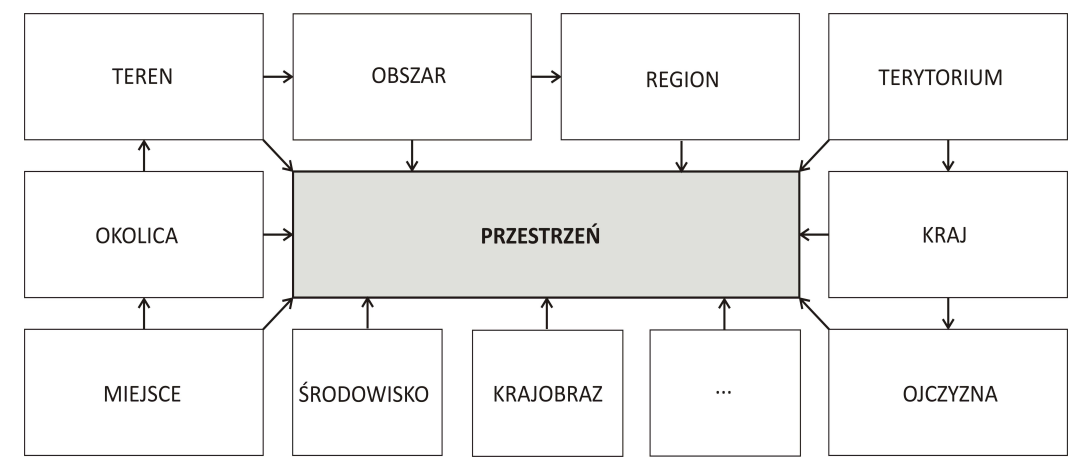

Rys. 1. Wybrane konteksty dosłownego (niemetaforycznego) rozumienia pojęcia "przestrzeń” Źródło: opracowanie autora na podstawie B. JAŁOWIECKI (2010)

Dosłowne pojmowanie i analiza przestrzeni może być prowadzona na różnych poziomach kognitywnych i emocjonalnych. Począwszy od „miejsca” mogącego być jedynie punktem w przestrzeni, ale najczęściej „oswojonego" i nacechowanego różnego rodzaju emocjami (TUAN 1987), przez obszar, region, aż do ojczyzny będącej nie tylko zbiorem miejsc, regionów, ale także wartością samą w sobie związaną $\mathrm{z}$ emocjami o nieco innym charakterze (JAŁOWIECKI 2010) - rys. 1.

Metaforyczne postrzeganie nie tylko otaczających człowieka elementów przestrzeni, ale także życia jako swego rodzaju spektaklu, podczas którego 
zachodzą skomplikowane relacje między reżyserami, aktorami i widzami, wydaje się być cechą charakterystyczną ery ponowoczesnej. Jedną z takich metafor proponuje Z. BAUMAN (1994), przypisując scenie życia cztery grupy aktorów, których role w dużej części nawiązują do podróży. Zarzucając niejako wcześniejsze, nowoczesne ujęcie „człowieka-pielgrzyma”, proponuje ponowoczesne role ",spacerowicza”, ,"włóczęgi”, , turysty" i ,gracza”. Role te ukazują odmienne relacje między człowiekiem a przestrzenią oraz innymi grupami aktorów. Ich syntetyczną charakterystykę można przedstawić następująco:

- spacerowicz to przechodzien, wszystko widzący, ale sam nie widziany, ukryty w tłumie, ale do tłumu nie należący, dla niego życie jest bardziej teatrem wyobraźni niż realnym spektaklem;

- włóczęga żyje w drodze i nie wie, co przyniesie następny dzień; goni za zmianą dla samej zmiany; jest zmuszony do wędrówki, szuka lepszego losu, musi być uległy w nowym środowisku;

- turysta opuszcza dom w poszukiwaniu wrażeń; ocenia świat zawsze w kontekście opuszczonego domu rodzinnego; wrażenia i opowieści, kolekcja przygód - to jedyny łup na którym mu zależy;

- gracz nie jest podróżnikiem; dla niego życie nie jest ruchem, lecz grą, serią kolejnych walk, rozgrywek, meczów, spotkań, porządkuje wszystko wokół siebie (w tym przestrzeń) według zasad, które często sam tworzy; jego działania często mają (ważny w przestrzeni) charakter zakulisowy (BAUMAN 1994, PODEMSKI 2004).

Jednostka, wkraczając w krąg bezpośredniej obecności innych jednostek, ma wiele powodów, aby próbować kontrolować wrażenie, jakie robi na innych (GOFFMAN 1981). Dotyczy to nie tylko turystów, dla których przygotowuje się scenę i spektakl, ale także pozostałych grup aktorów biorących udział w przedstawieniu. Jednostka (a wydaje się, że grupa tym bardziej dop. autora) wkraczając w krąg obecności innych, narzuca im swoją, czasem specyficzną i oryginalną definicję sytuacji (GOFFMAN 1981).

Przyjmując za podstawę rozważań tzw. perspektywę goffmanowską oraz definicje Innego stownika języka polskiego pod red. M. BAŃKO (2014) można pokusić się o rozwinięcie pojęć podstawowych, związanych z metaforycznym ujęciem przestrzeni jako sceny, do których należą m.in.:

1) scena - miejsce, w którym odbywa się występ, miejsce jakichś wydarzeń lub dziedzinę, w których one zachodzą. $W$ przyjętej koncepcji scena jest synonimem przestrzeni turystycznej; 
2) spektakl/występ/przedstawienie - wszelka działalność konkretnego uczestnika interakcji w konkretnej sytuacji, służąca wpływaniu w jakiś sposób na któregokolwiek z innych uczestników, publiczne wystąpienie nastawione na osiągnięcie określonych celów. Jest to zespół działań nastawionych na zaspokojenie potrzeb turysty, często z jego aktywnym udziałem. Tworzą go m.in. atrakcje i wydarzenia przygotowane specjalnie dla tej grupy aktorów;

3) scenariusz - np. jakichś wydarzeń, to ich przebieg, zwłaszcza zaplanowany lub prawdopodobny. W dłuższej perspektywie czasowej mogą to być strategie lub programy rozwoju turystyki określonego obszaru lub przedsiębiorstwa, w krótszej - wszelkie plany działań podejmowanych $\mathrm{w}$ celu przyciągnięcia turysty realizowane podczas jego pobytu w określonej przestrzeni;

4) aktor/zespół aktorski - w przypadku jakichś wydarzeń, ktoś kto w nich uczestniczył i zwykle miał w nich ważny udział, każda grupa osób współpracująca ze sobą w inscenizacji jakiegokolwiek fragmentu przedstawienia. $W$ przestrzeni turystycznej są to turyści, mieszkańcy, pracownicy branży turystycznej (aktorzy indywidualni) oraz przedsiębiorcy, organizacje i władze (aktorzy instytucjonalni);

5) publiczność/widz - ktoś, kto przygląda się czemuś, zwykle jakiemuś zdarzeniu, jednostki lub grupy obserwujące występ, ci którzy przyczyniają się do występów innych, ale nie biorą $\mathrm{w}$ nim bezpośredniego udziału. Tę grupę, w zależności od poziomu bezpośredniości udziału w spektaklu, stanowić mogą zarówno turyści, jak i mieszkańcy, będąc jednocześnie aktorami. $W$ relacjach z przestrzenią mogą to być także np. potencjalni turyści zastanawiający się nad wyborem destynacji;

6) statysta - ktoś, kto obserwuje jakieś zdarzenia, ale nie uczestniczy $\mathrm{w}$ nich. W przestrzeni turystycznej to grupa mieszkańców niezwiązana czynnie z rozwojem turystyki;

7) kulisy - miejsce, gdzie świadomie przeczy się wrażeniom, których wywołaniu ma służyć przedstawienie, miejsce, gdzie aktorzy wychodzą z roli. Czasem niedostępne dla niektórych grup (np. publiczności turystów, mieszkańców), a czasem celowo pokazywane, aby wywołać efekt niecodzienności, tajemniczości, niedostępności i wyjątkowości. Ważność kulis potwierdzają koncepcje zaprezentowane w dalszej części opracowania.

Porównanie życia codziennego do teatru według E. GofFMANA (1981) jest ,,jedną z socjologicznych perspektyw, z jakich można badać życie spo- 
łeczne”. W takim ujęciu także aktywność turystyczną zachodzącą w przestrzeni można traktować jako część (fragment) życia społecznego. Przy takim założeniu stwierdzenie: „obecność innych przekształca zachowanie ludzkie w przedstawienie, którego głównym celem jest wywarcie wrażenia” (GOFFMAN 1981) jest nadal aktualne także na scenie przestrzeni turystycznej, gdzie różne grupy aktorów odgrywają różne role, wywierając określone wrażenia i realizując przy tym konkretne interesy (prywatne, biznesowe, polityczne, społeczne).

Podobne ujęcie metaforyczne, przyrównujące przestrzeń turystyczną do sceny proponuje D. MACCANNELL (2002) nazywając przestrzeń, w zależności od relacji z turystami, scenerią turystyczną, scenografią lub inscenizacją. Wyodrębnia on za E. GOFFMANEM (1981) sześć stref (stadiów continuum) poznania turystycznego. Jednak strefy te jedynie w pewnym uproszczeniu można utożsamiać ze specyficznymi częściami przestrzeni turystycznej. Stanowią je kolejno:

1) strefa I - scena (strefa fasadowa), którą turysta chce przekroczyć, by dostać się za kulisy, aby poznać to, co niedostępne dla „zwykłych" $\mathrm{i}$,"niewtajemniczonych";

2) strefa II - scena $\mathbf{z}$ dekoracjami stanowiącymi powierzchowne upiększenie potrzebne dla zbudowania atmosfery, podobna nieco do zakazanej strefy kulis, ale będąca tylko ich namiastką;

3) strefa III - scena zaaranżowana tak, by wyglądała jak kulisy, a niektórzy „widzowie dają się nabrać” na ich pozorną autentyczność;

4) strefa IV - otwarta część kulis, w której nie wszystko jednak można zobaczyć;

5) strefa V - kulisy otwarte, ale nieco zmienione, ponieważ turyście wolno czasami tam zajrzeć, ale nadal nie wszystko jest możliwe do zobaczenia;

6) strefa VI - kulisy niedostępne dla turysty, które z założenia mają być zamknięte i pozostawiać niedosyt wrażeń oraz informacji.

Nie podważając trafności tych spostrzeżeń stwierdzić należy jedynie, że w przedstawionej koncepcji turysta, jeden z głównych podmiotów przestrzeni turystycznej, potraktowany został bardziej jako widz, niż jako aktor mający realny wpływ na rozgrywający się spektakl, zarówno na scenie, jak za jej kulisami. W dalszej części rozważań turysta, główny podmiot przestrzeni wchodzący w relacje z innymi jednostkami (grupami), będzie traktowany jako jeden $\mathrm{z}$ głównych aktorów przestrzeni turystycznej. 


\section{Role człowieka w przestrzeni turystycznej}

Rozpatrując przestrzeń turystyczną nie tylko z punktu widzenia tworzących ją składników, ale także zachodzących procesów i działań w niej podejmowanych, nie można pominąć ról, jakie odgrywa człowiek w niej funkcjonujący. Pod pojęciem „rola” w niniejszym opracowaniu rozumiany jest „udział i znaczenie kogoś, czegoś w jakichś okolicznościach, w jakimś przedsięwzięciu; stanowisko zajmowane przez kogoś $\mathrm{w}$ jakiejś sprawie; zadanie do spełnienia; pozycję zajmowaną w czymś, występowanie w jakimś charakterze" (Stownik jezyka polskiego 1978). Inny stownik jezzyka polskiego pod red. M. BAŃKO (2014) jako jeden z kontekstów pojęcia „rola” podaje: „rola jakiejś osoby lub instytucji, jakiegoś miejsca to ich zadanie lub znaczenie". Zatem rolę człowieka w przestrzeni turystycznej zdefiniować można jako jego udział, miejsce i znaczenie w tworzeniu tej przestrzeni. Generalnie działania człowieka (grup aktorów) w przestrzeni turystycznej można sprowadzić do kilku podstawowych ról. Możemy zatem mówić o człowieku jako:

1) organizatorze (twórcy) przestrzeni turystycznej (przedsiębiorcy, samorząd terytorialny, władze administracyjne, organizacje społeczne) rolą tą, oprócz wymienionych wcześniej grup, objęci są także przedsiębiorcy, którzy mają największy wpływ na techniczną stronę funkcjonowania przestrzeni (budowa infrastruktury turystycznej). Jednym z podstawowych zadań przedsiębiorców (zarówno wewnętrznych, jak i zewnętrznych) jest kreacja przestrzeni turystycznej jako konkretnego produktu turystycznego, którego sprzedaż i konsumpcja przynosi określone korzyści wszystkim „aktorom” (przedsiębiorcy - dochody, władze - kapitał polityczny, mieszkańcy - poprawa jakości życia) (KACZMAREK, STASIAK, WŁODARCZYK 2010);

2) konsumencie przestrzeni turystycznej (turyście) - ponieważ wykazuje on różnorodne potrzeby i oczekiwania, posiada różne możliwości (ekonomiczne, czasowe), które decydują o wyborach określonych przestrzeni. Jego opinie na temat samej przestrzeni i poziomu spełnienia przez nią oczekiwań (mające wyraz formalny bądź nieformalny) pośrednio wpływają na charakter działań podejmowanych przez innych użytkowników tej przestrzeni. Bezpośrednie zachowania turystów w przestrzeni mogą także decydować o jej jakości. Przyjmując za J. KACZMARKIEM, A. STASIAKIEM i B. WŁODARCZYKIEM (2010), że aktywność turystyczna jest częścią tzw. odświętnej sfery życia człowieka można przyjąć także, że zachowania (role) turysty będą miały w prze- 
strzeni turystycznej inny (czasem skrajnie różny) charakter od granych w życiu codziennym;

3) stymulatorze wyboru przestrzeni turystycznej - rola ta bezpośrednio związana z konsumpcją konkretnych przestrzeni (porównaj rola konsumenta-turysty) wynika ze znanej z socjologii turystyki "teorii towarzystwa" (BIRŻAKOW 2005). Polega ona na pośrednim wpływie jednych turystów na wybór określonych przestrzeni przez innych. W tym przypadku motywem wyboru może być np. namowa krewnych, znajomych lub wyjazd grupy rówieśniczej, a chęć pobytu z innymi jest silniejsza, niż indywidualne preferencje związane $z$ wyborem konkretnej przestrzeni turystycznej. Tak więc, to nie tylko przestrzeń oraz jej cechy i właściwości decydują o wyborze, ale także obecność w niej innych turystów;

4) mieszkańcu przestrzeni turystycznej (społeczność lokalna) - rola ta powinna być rozumiana nie tylko jako rola gospodarza czy organizatora przestrzeni, ale przede wszystkim jako rola jednostki czy społeczności żyjącej w konkretnej przestrzeni. Charakteryzując przestrzeń należy odpowiedzieć także na pytanie, czy podejmowane w niej działania nastawione głównie na spełnienie oczekiwań turystów zaspokajają także potrzeby jej mieszkańców (problem jakości życia w określonej przestrzeni). Z punktu widzenia korzyści związanych z funkcjonowaniem przestrzeni turystycznej, jej mieszkańców możemy podzielić na trzy podstawowe grupy:

- osoby odnoszące bezpośrednie korzyści z funkcjonowania przestrzeni turystycznej (najemcy kwater, wytwórcy pamiątek, sprzedawcy żywności, inni pracownicy branży turystycznej) zazwyczaj przychylnie nastawione do zmian związanych z jej rozwojem, które jednocześnie przyczyniają się do poprawy warunków ich życia;

- osoby nieodnoszące bezpośrednich korzyści z funkcjonowania przestrzeni turystycznej, ale przychylnie nastawione do jej rozwoju, upatrujące w nim szanse na poprawę jakości życia całej lokalnej społeczności (np. członkowie organizacji turystycznych);

- osoby nieodnoszące bezpośrednich korzyści z funkcjonowania przestrzeni turystycznej i niezainteresowane jej rozwojem, czasem krytycznie odnoszące się do wszelkich podejmowanych w niej działań i przeciwne rozwojowi tej przestrzeni, niedostrzegające korzyści z jej funkcjonowania. Istotne dla rozwoju i funkcjonowania tej prze- 
strzeni są proporcje i relacje między przedstawicielami wymienionych wcześniej grup mieszkańców;

5) gospodarzu przestrzeni turystycznej (władze lokalne, mieszkańcy) rola ta polega na reprezentowaniu przestrzeni nie tylko przez jej mieszkańców, ale także przez władze administracyjne, samorządowe, organizacje turystyczne wobec turystów-gości, poprzez wypracowanie oryginalnej formuły gościnności, a w konsekwencji wykreowaniu tzw. przestrzeni gościnnej (KACZMAREK, KACZMAREK 2011). Rola gospodarza to także aktywne działania promocyjne, budowanie pozytywnego wizerunku, przełamywanie negatywnych stereotypów związanych z funkcjonowaniem konkretnej przestrzeni turystycznej;

6) „atrakcji turystycznej” - ponieważ niektóre z przestrzeni turystycznych bez zamieszkujących je ludzi z ich dziedzictwem kulturowym, zwyczajami, obrzędami, świętami czy choćby codziennym życiem, czasami bardzo odmiennymi od tych, które reprezentują turyści, jawiłyby się jako przestrzenie „puste”, nieciekawe, mało interesujące. Wynika stąd, że to człowiek-mieszkaniec w wielu przypadkach jest motywem podejmowanych wyjazdów w konkretną przestrzeń, a będąc jej częścią (także częścią jej potencjału) staje się mimowolnie lub świadomie (motywacje komercyjne) turystyczną atrakcją.

\section{Aktorzy przestrzeni turystycznej}

Jak zauważa B. JAŁOWIECKI (2010, s. 44-45):

Przestrzeń jest produktem społecznym, jest wytwarzana nie przez tajemnicze siły biologiczne czy podspołeczne, ale przez konkretnych ludzi działających w realnie, historycznie ukształtowanych strukturach społecznych. Każda przestrzeń jest korelatem klas, warstw i grup społecznych. Za każdą formą przestrzenną kryją się aktorzy, którzy ją wytworzyli zgodnie ze swoimi interesami i ideologią i których potrzeby zaspokaja. Mówiąc najbardziej ogólnie, przestrzeń jest wytworem żywej struktury, grupy społecznej, która traktuje ją jako środek zachowania swojej struktury.

Wymienione wcześniej role można przypisać grupom aktorów mającym bezpośredni lub pośredni wpływ na badaną przestrzeń. Należy przy tym przyjąć, że te same role mogą być grane przez różne grupy aktorów. Na przykład rola gospodarza przestrzeni turystycznej może być charakterystyczna zarówno dla mieszkańców, władz czy organizacji działających 
w określonej przestrzeni. Generalnie w przestrzeni można wyróżnić sześć grup aktorów (rys. 2), z czego trzy grupy można sklasyfikować jako tzw. aktorów indywidualnych (kolor szary ciemniejszy) oraz aktorów grupowych/ zespołowych (kolor szary jaśniejszy).

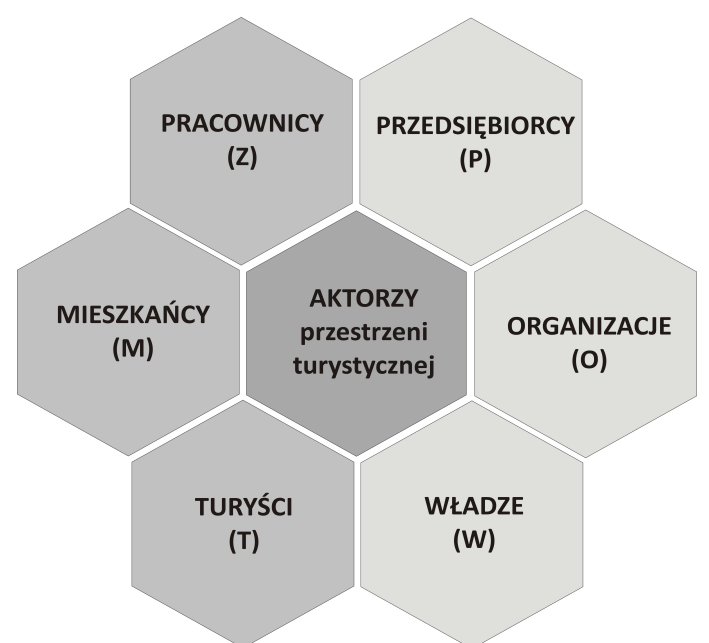

Rys. 2. Grupy aktorów przestrzeni turystycznej Źródło: opracowanie własne

Zaliczamy do nich (por. tab. 1):

- turystów (T) (konsumenci przestrzeni turystycznej) - którzy stanowiąc „element egzogeniczny” przestrzeni turystycznej, poprzez wykazywane preferencje i zainteresowania związane $z$ formami aktywności turystycznej stymulują działania podejmowane przez inne grupy aktorów (pośredni wpływ na przestrzeń). W wyniku podejmowania konkretnych, indywidualnych działań o charakterze eksploracyjnym, penetracyjnym czy kolonizacyjnym (np. budowa drugich domów) bezpośrednio wpływają na zajmowaną przestrzeń oraz pozwalają na określenie jej typu. Traktując dosłownie metaforę człowieka-turysty Z. BAUMANA (1994, s. 31) można zacytować:

Turysta nie wystawia swych sztuk w teatrze wyobraźni, jak to czyni spacerowicz: chce, by aktorzy grali naprawdę, dobierając scenariusze odpowiednio do jego upodobań. Aktorzy mają być świadomi jego wymagań, a wymagania te kierować mają ich postępowaniem. Turysta jest artystą; turystyka jest twórczością. Świat przez turystę odwiedzany jest surową bryłą marmuru, której turysta nada kształt swoich przeżyć. 
Tab. 1. Różnorodny charakter ról głównych grup aktorów przestrzeni turystycznej

\begin{tabular}{|c|c|c|c|}
\hline \multirow[b]{2}{*}{ Aktorzy } & \multicolumn{3}{|c|}{ Role } \\
\hline & I plan & II plan & $\begin{array}{c}\text { statyści/widzowie/ } \\
\text { obserwatorzy }\end{array}$ \\
\hline Turyści & $\begin{array}{l}\text { Wymagający, zorganizo- } \\
\text { wani lub indywidualni; } \\
\text { widoczny w przestrzeni } \\
\text { z powodu zwracających } \\
\text { uwage postaw i zacho- } \\
\text { wań; narzucający swoją } \\
\text { obecność. }\end{array}$ & $\begin{array}{l}\text { Indywidualni lub zorga- } \\
\text { nizowani w niewielkie gru- } \\
\text { py; poszukujący spokoju; } \\
\text { zainteresowani zajmowa- } \\
\text { niem nisz w przestrzeni; } \\
\text { stroniący od przestrzeni } \\
\text { modnych i agresywnie } \\
\text { konsumowanych. }\end{array}$ & $\begin{array}{l}\text { Potencjalni użytkownicy } \\
\text { przestrzeni; zaintereso- } \\
\text { wani aktualnymi wyda- } \\
\text { rzeniami; poszukujący } \\
\text { informacji, które mogą } \\
\text { zadecydować o wyborze } \\
\text { miejsca recepcyjnego. }\end{array}$ \\
\hline $\begin{array}{l}\text { Przedsię- } \\
\text { biorcy }\end{array}$ & $\begin{array}{l}\text { Firmy tzw. formalnego } \\
\text { sektora turystyki (tour- } \\
\text { operatorzy, łańcuchy } \\
\text { hotelowe, parki rozrywki, } \\
\text { obiekty gastronomiczne. }\end{array}$ & $\begin{array}{l}\text { Firmy wspomagające sek- } \\
\text { tor turystyczny (np. do- } \\
\text { stawcy półproduktów do } \\
\text { gastronomii). }\end{array}$ & $\begin{array}{l}\text { Firmy incydentalnie } \\
\text { związane z sektorem } \\
\text { turystycznym, w których } \\
\text { turystyka nie stanowi } \\
\text { podstawy działalności. }\end{array}$ \\
\hline $\begin{array}{l}\text { Pracownicy } \\
\text { branży } \\
\text { turystycznej }\end{array}$ & $\begin{array}{l}\text { Część personelu mająca } \\
\text { bezpośredni kontakt z tu- } \\
\text { rystami (tzw. front office) - } \\
\text { zarówno sektor formalny } \\
\text { jaki i nieformalny. }\end{array}$ & $\begin{array}{l}\text { Część personelu nie mająca } \\
\text { bezpośredniego kontaktu z } \\
\text { turystami (tzw. back office) - } \\
\text { zarówno sektor formalny } \\
\text { jak i nieformalny. }\end{array}$ & $\begin{array}{l}\text { Poszukujący pracy, roz- } \\
\text { ważający możliwość za- } \\
\text { trudnienia w sektorze } \\
\text { turystycznym. }\end{array}$ \\
\hline $\begin{array}{l}\text { Władze pań- } \\
\text { stwowe i sa- } \\
\text { morządowe }\end{array}$ & $\begin{array}{l}\text { Ustawodawcy, decydenci } \\
\text { w zakresie polityki prze- } \\
\text { strzennej i gospodarczej } \\
\text { związanej z turystyką. }\end{array}$ & $\begin{array}{l}\text { Instytucje wspierające roz- } \\
\text { wój turystyki w określonej } \\
\text { przestrzeni. }\end{array}$ & $\begin{array}{l}\text { Instytucje niezaintereso- } \\
\text { wane rozwojem turystyki } \\
\text { w zarządzanej prze- } \\
\text { strzeni. }\end{array}$ \\
\hline $\begin{array}{l}\text { Organizacje } \\
\text { i stowarzy- } \\
\text { szenia }\end{array}$ & $\begin{array}{l}\text { Ich podstawowym za- } \\
\text { daniem jest działalność } \\
\text { bezpośrednio związana } \\
\text { z turystyką, (stowarzy- } \\
\text { szenia, lokalne, regio- } \\
\text { nalne organizacje tury- } \\
\text { styczne, kluby turystycz- } \\
\text { ne itp.). }\end{array}$ & $\begin{array}{l}\text { W ich działalności turysty- } \\
\text { ka jest jednym z (nie naj- } \\
\text { ważniejszym) aspektów } \\
\text { działalności (np. organi- } \\
\text { zacje młodzieżowe). }\end{array}$ & $\begin{array}{l}\text { Np. organizacje konsu- } \\
\text { menckie, firmy konsul- } \\
\text { tingowe, instytucje bada- } \\
\text { jące zjawiska turystyczne. }\end{array}$ \\
\hline Mieszkańcy & $\begin{array}{l}\text { Zatrudnieni w sekto- } \\
\text { rze turystycznym lub } \\
\text { działający na jego } \\
\text { korzyść w organiza- } \\
\text { cjach i stowarzyszeniach; } \\
\text { będący „atrakcją tury- } \\
\text { styczną". }\end{array}$ & $\begin{array}{l}\text { Traktujący turystykę jako } \\
\text { dodatkowe źródło docho- } \\
\text { dów, czasem z jakiegoś } \\
\text { powodu wzbudzający } \\
\text { zainteresowanie turystów. }\end{array}$ & $\begin{array}{l}\text { Mieszkańcy obszaru nie } \\
\text { związani działalnością } \\
\text { turystyczną w badanej } \\
\text { przestrzeni. }\end{array}$ \\
\hline
\end{tabular}

Źródło: opracowanie własne. 
- mieszkańców (M) (osoby zamieszkujące obszar, niezajmujące się zawodową obsługą ruchu turystycznego, a turystyka może być dodatkowym źródłem dochodu, czasami zrzeszone $\mathrm{w}$ organizacjach społecznych) - którzy z racji bycia częścią przestrzeni turystycznej mają na nią zazwyczaj znaczący wpływ. Nie ogranicza się on jedynie, jak można byłoby się spodziewać, do przestrzeni asymilacji turystycznej, w której jest najbardziej czytelny (wpływ bezpośredni), ale ze względu na charakter społeczności lokalnych (otwarte lub hermetyczne) współdecyduje o „klimacie”, sprzyjającym lub nie, podejmowaniu działań na rzecz turystyki (wpływ pośredni). W przypadku organizacji społecznych celem prowadzonej $\mathrm{w}$ przestrzeni turystycznej działalności są nie tylko partykularne interesy ich członków, ale także szeroko rozumiane korzyści społeczne;

- organizacje i stowarzyszenia (O) (grupa, która może być wypadkową działań mieszkańców i podmiotów branżowych funkcjonujących $\mathrm{w}$ analizowanych przestrzeniach). W skład tej grupy zazwyczaj wchodzą organizacje społeczne i kluby turystyczne, stowarzyszenia miłośników, lokalne i regionalne organizacje turystyczne. Ich wspólną cechą jest misyjność działania, która ma doprowadzić np. do zachowania lub poprawy stanu i wartości przestrzeni, poprawy warunków (jakości) życia jej mieszkańców, czasem zewnętrznego reprezentowania regionu;

- przedsiębiorców (P) (grupa reprezentująca zarówno interesy ekonomiczne osób spoza charakteryzowanej przestrzeni, nie będących jej mieszkańcami, jak i będących elementem struktur gospodarczych badanej przestrzeni) - których wspólną cechą jest ekonomiczny motyw podejmowania działań na rzecz turystyki. Ta grupa aktorów ma wpływ zarówno na organizację turystyki jako zjawiska, jak i na kształt produktu turystycznego, będącego częścią przestrzeni turystycznej rozpatrywanej na płaszczyźnie ekonomicznej i konsumowanego w tej przestrzeni. Poza przestrzeniami eksploracji i asymilacji ich wpływ jest wyraźnie zauważalny we wszystkich pozostałych typach przestrzeni (wpływ bezpośredni);

- pracowników branży turystycznej (Z) (grupa osób bezpośrednio związana z opisaną poprzednio, z tą różnicą, że nie podejmująca decyzji o większym, strategicznym znaczeniu dla przestrzeni turystycznej), których wpływ na przestrzeń jest równie istotny ze względu na bezpośrednie relacje $\mathrm{z}$ turystami (pracownicy tzw. front office) co ja- 
kość oferowanego w przestrzeni produktu (także pracownicy back office). Mogą to być zarówno mieszkańcy, jak i osoby spoza omawianej przestrzeni;

- władze (W) (zarówno państwowe, jak i samorządowe na różnych poziomach decyzyjnych), będące często przedstawicielami lokalnych społeczności i mające generalnie pośredni wpływ na organizację przestrzeni turystycznej. Podejmowane decyzje ze względu na swój charakter i wagę mogą jednak decydować o kierunkach rozwoju badanego obszaru (strategie i plany rozwoju turystyki). W przypadku proturystycznej polityki tej grupy aktorów najważniejsze działania dotyczą wszelkiego rodzaju udogodnień i zachęt umożliwiających lub ułatwiających podejmowanie działalności w badanej przestrzeni przez pozostałe grupy. Efektem tych działań nie są zazwyczaj jedynie korzyści o charakterze czysto ekonomicznym (np. dodatkowe dochody, miejsca pracy czy nowa lub zmodernizowana infrastruktura), lecz także korzyści społeczne (poprawa warunków życia, integracja społeczności lokalnych wokół wspólnego celu itp.) oraz w wielu przypadkach zysk (kapitał) polityczny.

Wspólnymi cechami wszystkich przedstawionych grup „aktorów” na scenie przestrzeni turystycznej są: osiąganie określonych korzyści jako cel prowadzonej działalności, fakt że ich działania odbywają się w środowisku prawnym i każdy podmiot jest zobowiązany do przestrzegania uregulowań legislacyjnych, a w strukturach związanych z zarządzaniem istotną rolę odgrywa lider, znacząca osobowość kierująca zasobami ludzkimi i finansowymi (KACZMAREK, STASIAK, WŁODARCZYK 2010).

Rola przywództwa (lidera/reżysera) i jej znaczenie w przestrzeni turystycznej w bardzo klarowny sposób scharakteryzowane zostały przez P. ZMYŚLONEGO (2008), który pisze m.in. że liderem (przywódcą) mogą być rzadziej jednostki (osoby), a częściej funkcjonujące organizacje (władze lokalne, przedsiębiorstwa, instytucje otoczenia rynkowego). Rolę przywódcy mogą także odgrywać specjalnie powołane w określonym celu organizacje działające na zasadzie partnerstwa (rys. 3).

Charakteryzując zagadnienie lidera w określonej przestrzeni turystycznej (regionie, mieście itp.) można wyróżnić dwa rodzaje przywództwa: sensu stricto (jeden lub kilka indywidualnych podmiotów bezpośrednio w stosunku do innych podmiotów - władze lokalne, przedsiębiorstwa) i sensu largo (podmioty występujące w formie struktur partnerskich - lokalne i re- 


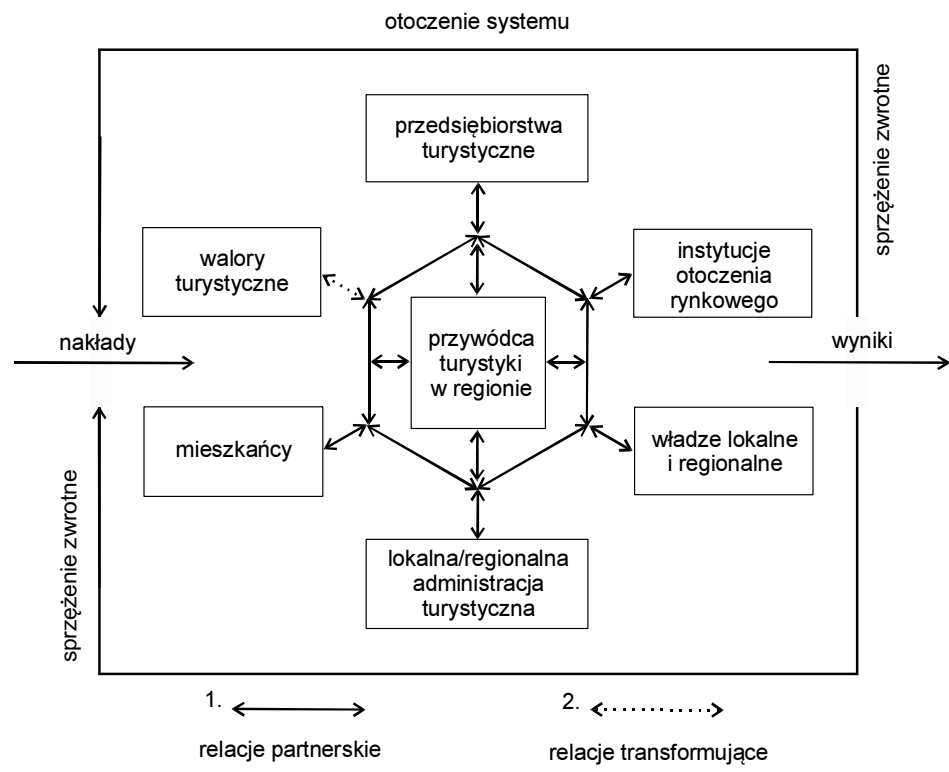

Rys. 3. Przywództwo w systemie turystyki $\mathrm{w}$ regionie (w przestrzeni turystycznej regionu dop. autora) według P. ZMYŚLONEGO (2008)

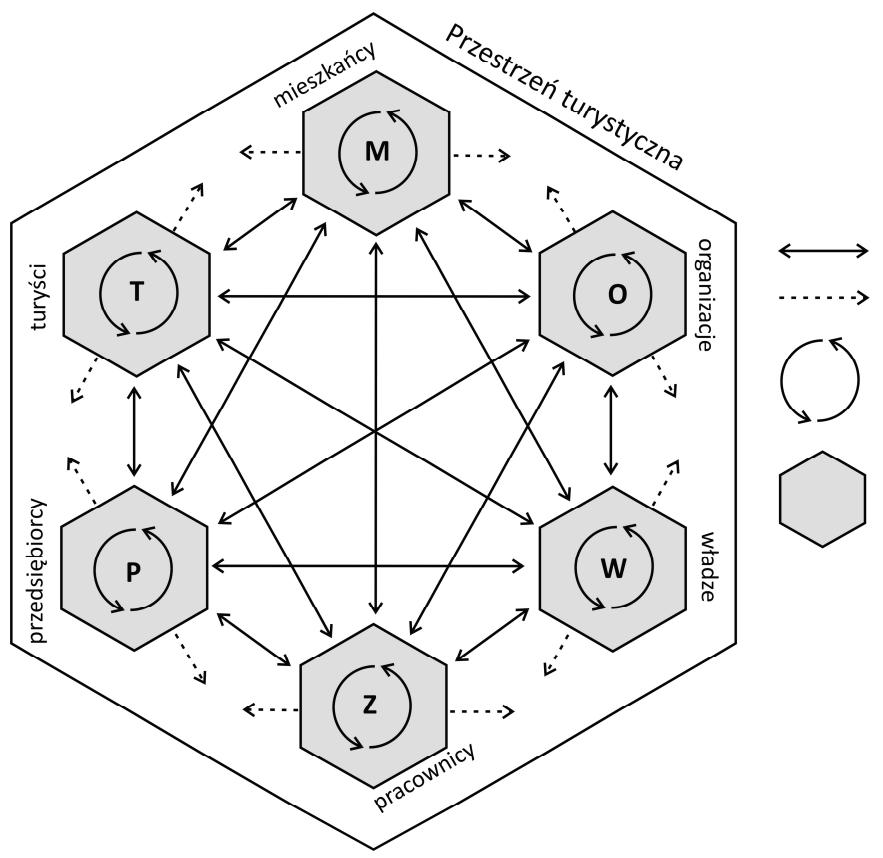

1.

2. Rys. 4. Związki i zależności między „aktora-

3. mi" przestrzeni tury-

stycznej

Objaśnienia:

1 - relacje między grupami aktorów przestrzeni turystycznej

2 - relacje między aktorami i przestrzenią

3 - relacje w ramach jednej grupy aktorów

4 - grupy aktorów

Źródło: B. WŁODARCZYK (2009) - zmienione 
gionalne organizacje turystyczne, związki samorządów, instytucje otoczenia rynkowego) (ZMYŚLONY 2008).

Wymienione grupy aktorów, oprócz wyraźnego wpływu na przestrzeń, charakteryzują także różnego rodzaju wzajemne relacje (rys. 4, tab. 2).

Realizowana przez jednostkę lub grupę społeczną aktywność turystyczna wymusza podejmowanie różnorodnych działań przez władze i społeczności lokalne związanych z organizacją (zagospodarowywaniem) przestrzeni geograficznej i przystosowaniem jej do potrzeb turystyki (działania na rzecz turystyki). Podobne zależności (zazwyczaj rzadziej) mogą zachodzić w kierunku odwrotnym, gdy działania podejmowane przez władze i społeczności lokalne (inwestycje turystyczne, nowe formy zagospodarowania turystycznego itp.) stymulują aktywność turystyczną jednostek lub grup społecznych. Jednak działania te w początkowym okresie rozwoju funkcji turystycznej bardzo często ograniczają się do niezbędnego minimum związanego z obsługą administracyjną obszaru. Kolejną grupą mającą istotny wpływ na rozwój form aktywności turystycznej są przedsiębiorcy (lokalni i zewnętrzni), którzy pojawiają się zazwyczaj jako ostatni, lecz mają równie znaczący wpływ na organizację przestrzeni turystycznej jak grupy wspomniane wcześniej (turyści, władze i społeczności lokalne). W związku z tym, że działania podejmowane przez przedsiębiorców właściwie nie mogą odbywać się bez zgody i kontroli władz lokalnych zostały one zaliczone do wspólnej grupy "działań na rzecz turystyki” stanowiących jeden z głównych elementów "aktywności turystycznej sensu largo" (WŁODARCZYK 2009).

W celu doprecyzowania stosowanych pojęć przyjmijmy zatem, że:

- aktywność turystyczna sensu largo to zdolność człowieka do uprawiania turystyki, uprawianie turystyki, czynne zajmowanie się turystyką, działania na rzecz turystyki. Aktywność turystyczna sensu largo nie jest synonimem ruchu turystycznego. Wspomniana „zdolność do uprawiania turystyki" $w$ niniejszym opracowaniu traktowana jest jako tzw. potencjalna aktywność turystyczna człowieka;

- aktywność turystyczna sensu stricto wyraża się poprzez czynne (wymagające od człowieka większego lub mniejszego zaangażowania) uprawianie turystyki (np. turystyka kwalifikowana, wypoczynek na działkach letniskowych, zajęcia rekreacyjne itp.) (Włodarczyk 1999, cyt. za WŁODARCZYK 2006).

W dalszej części rozważań termin "aktywność turystyczna człowieka” używany będzie skrótowo jako aktywność turystyczna. Termin ten w miarę potrzeb będzie precyzowany, np. aktywność turystyczna jednostki, grupy 


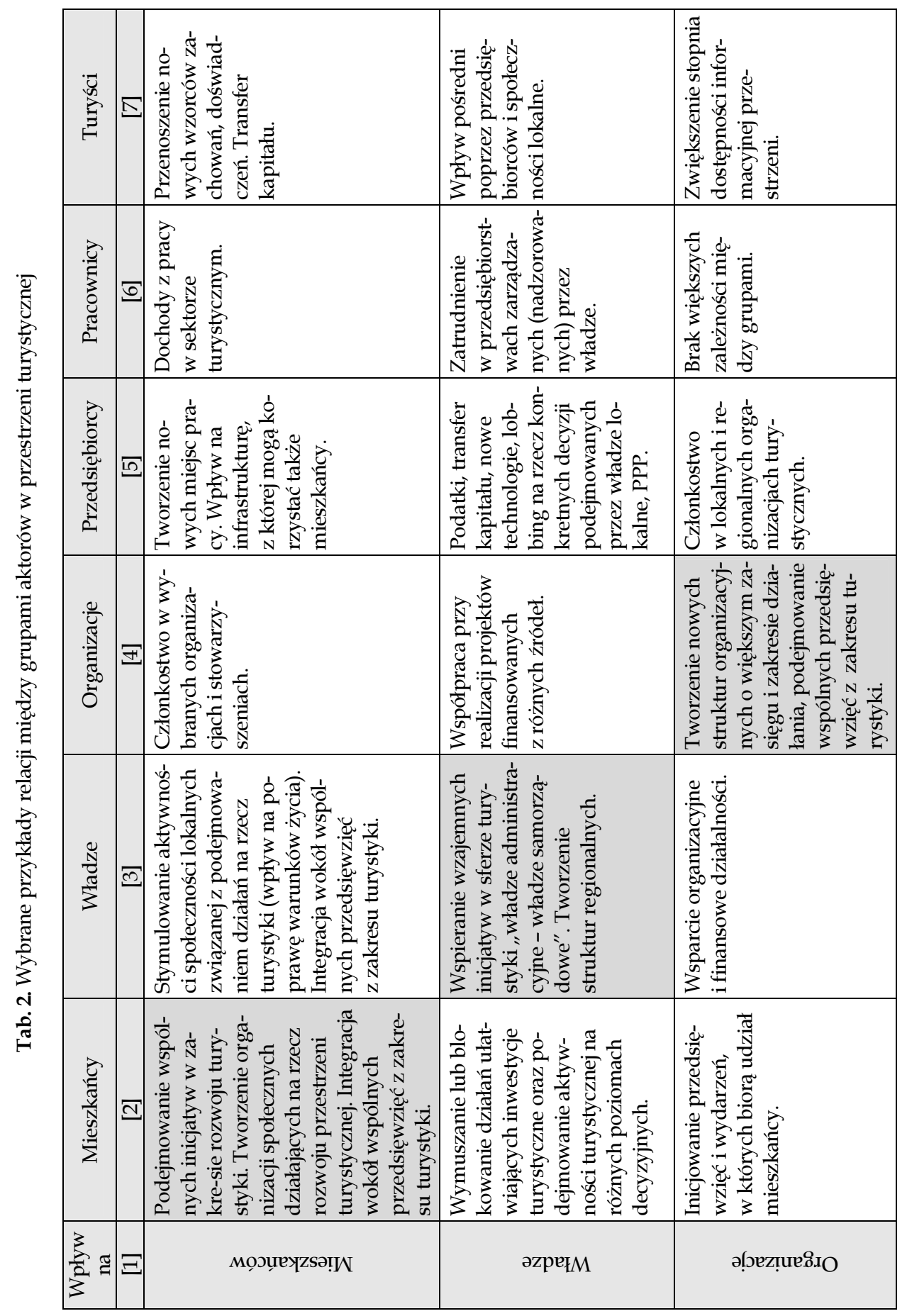




\begin{tabular}{|c|c|c|c|}
\hline$\Sigma$ & 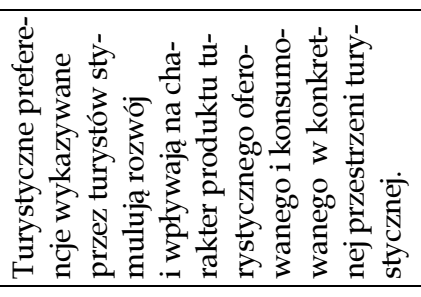 & 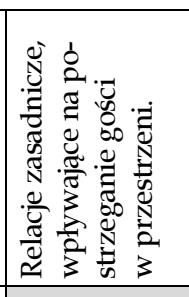 & 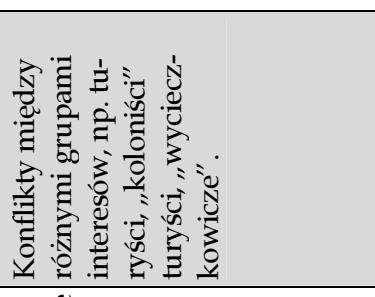 \\
\hline అ & 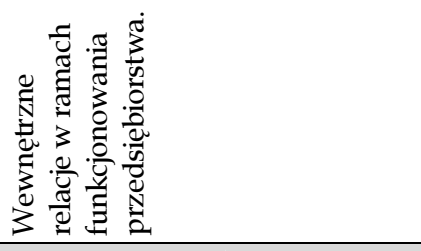 & 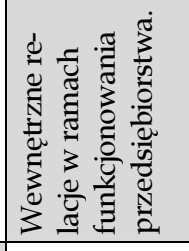 & 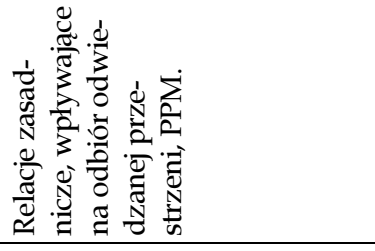 \\
\hline$\underline{n}$ & 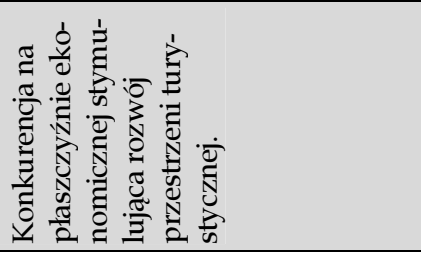 & 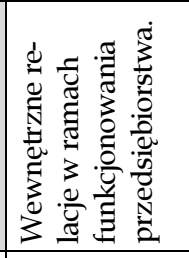 & 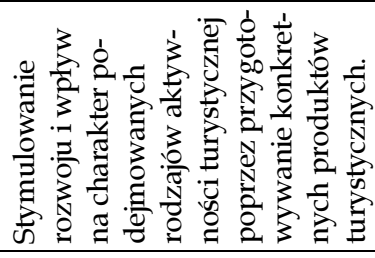 \\
\hline$\Xi$ & 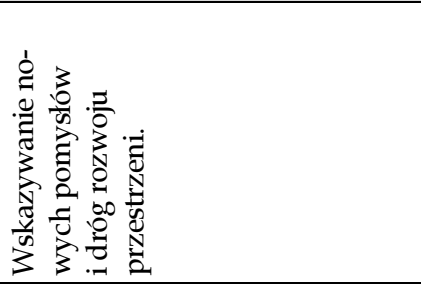 & 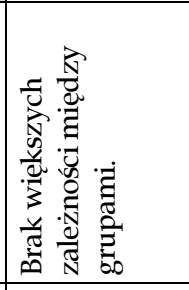 & 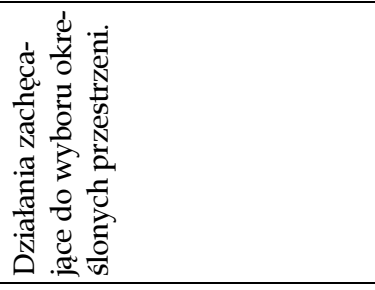 \\
\hline ल & 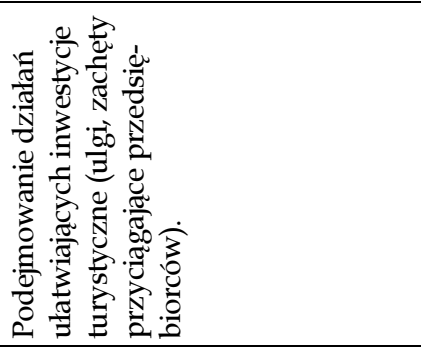 & 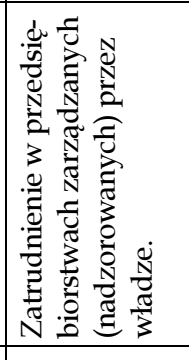 & 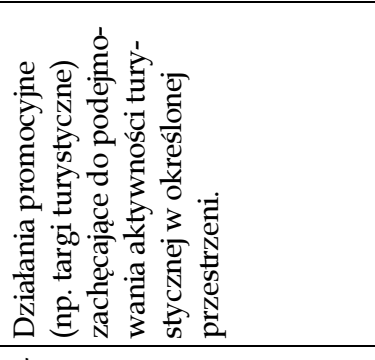 \\
\hline$\underline{\Xi}$ & 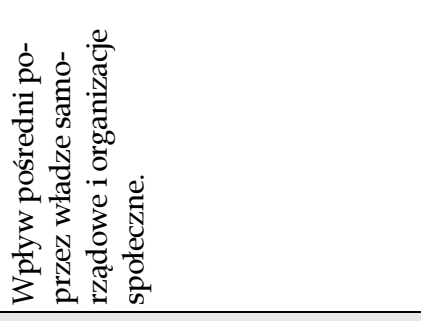 & 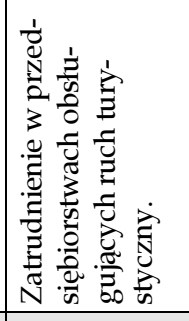 & 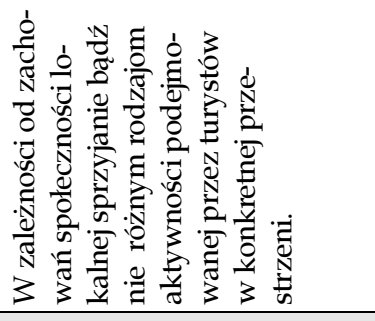 \\
\hline$\Xi$ & 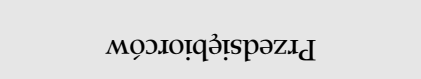 & Кэтимоэех $\mathrm{d}_{\mathrm{d}}$ & 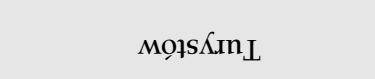 \\
\hline
\end{tabular}

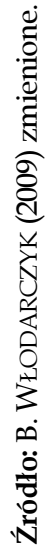


społecznej, społeczności itd. Precyzyjne zdefiniowanie pojęcia „aktywność turystyczna" jest o tyle istotne, że jest niezbędne do określenia indywidualnej przestrzeni turystycznej człowieka (ujęcie subiektywne), w odróżnieniu od funkcji turystycznej, będącej obiektywnym miernikiem realnej przestrzeni turystycznej (z punktu widzenia obszaru).

Potrzeba aktywności turystycznej powoduje, że człowiek podejmuje liczne działania doprowadzające do zmian w przestrzeni, w której ta aktywność zachodzi. Działania te mogą mieć charakter nieumyślnego przekształcania przestrzeni geograficznej, pojawiającego się w związku z uprawianymi formami turystyki, lub celowego przekształcania przestrzeni geograficznej, którego zadaniem jest przystosowanie przestrzeni, tak aby umożliwiała optymalnie realizację preferowanych form aktywności turystycznej. Dla uściślenia przyjmijmy więc, że:

- nieumyślne przekształcanie przestrzeni geograficznej to wszystkie przejawy aktywności turystycznej człowieka (turysty) niepozostawiające trwałych elementów zagospodarowania turystycznego;

- celowe przekształcanie przestrzeni geograficznej to wszelkie działania indywidualne lub grupowe mające na celu przystosowanie (zaadaptowanie) przestrzeni geograficznej do potrzeb wypoczynku i rekreacji (m.in. trwałe elementy zagospodarowania turystycznego, osadnictwo turystyczne);

- działania na rzecz turystyki to wszelkie przejawy działalności indywidualnej i zbiorowej (z wyłączeniem działań podejmowanych przez turystów), przystosowujące środowisko (przestrzeń geograficzną) do potrzeb uprawiania turystyki, bądź ułatwiające uprawianie turystyki na określonym obszarze $\mathrm{w}$ celu osiągnięcia określonych korzyści społecznych lub ekonomicznych (WŁODARCZYK 2009).

Analizując zachowania turystów indywidualnych bądź zorganizowanych $\mathrm{w}$ grupy celowe (penetracyjne czy kolonizacyjne) zauważyć możemy pewną dwoistość podejmowanych działań. Pierwszy kierunek, reprezentowany głównie przez jednostki bądź grupy eksploracyjno-penetracyjne, może być zasadniczo utożsamiany $\mathrm{z}$ pojęciem aktywności turystycznej sensu stricto. Kierunek ten prowadzi do wytworzenia jednej, dominującej, bądź kilku wspólegzystujących form tej aktywności, które w uproszczeniu mogą być utożsamiane $\mathrm{z}$ formami ruchu turystycznego. Realizacja tych form prowadzi do nieumyślnego przekształcania przestrzeni geograficznej (rys. 5). 

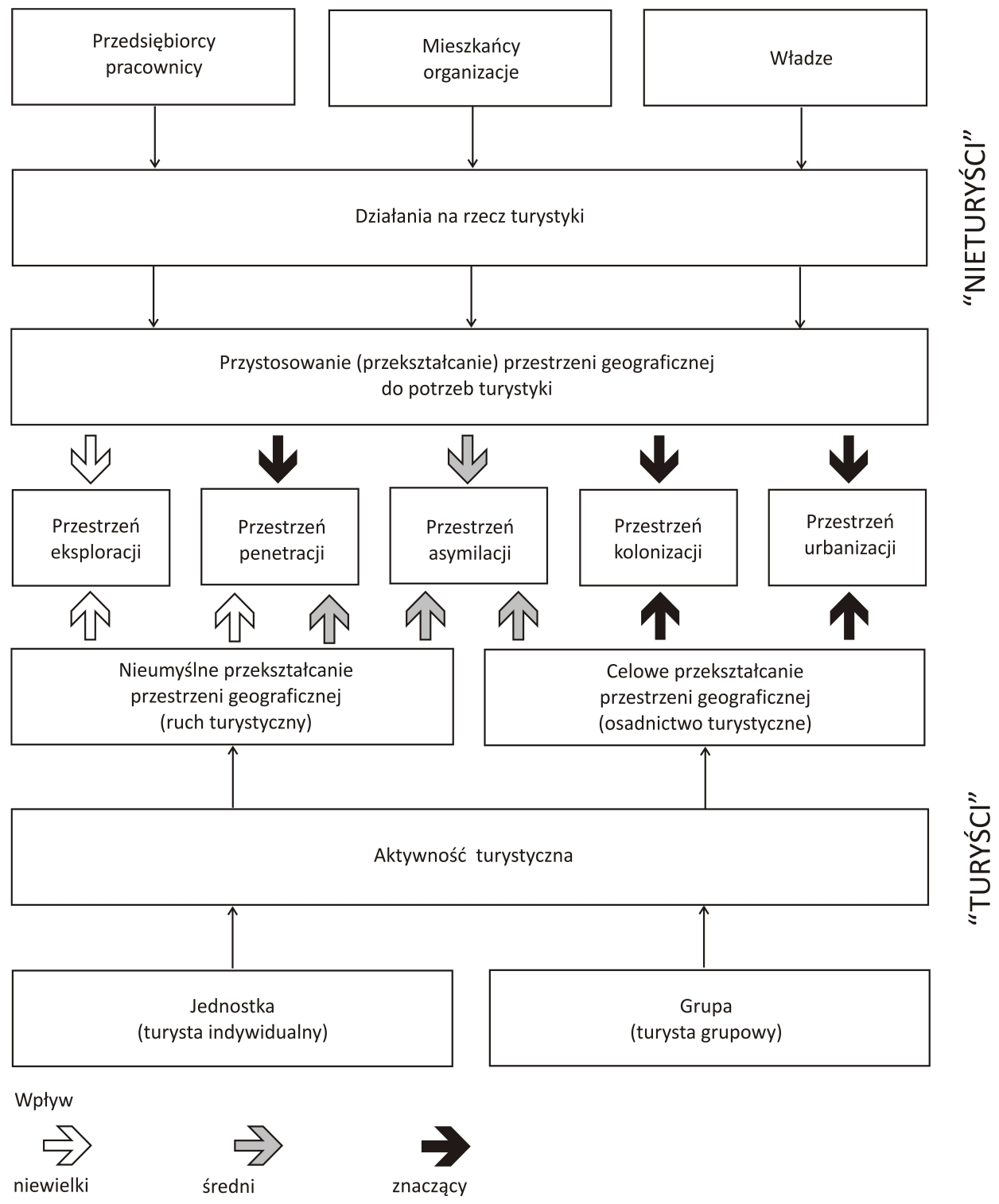

Rys. 5. Kształtowanie typów przestrzeni turystycznej przez różne grupy aktorów Źródło: B. WŁODARCZYK (2009) - zmienione

Nieumyślne przekształcanie przestrzeni geograficznej oraz formy aktywności turystycznej z nim związane nie powodują większych zmian morfologicznych i fizjonomicznych w przestrzeni, na której są obserwowane. 
Efekty tego działania oprócz niewielkich zmian funkcjonalnych, polegających na wzroście zainteresowania obszarem, praktycznie nie prowadzą do powstania obiektów stałego zainwestowania turystycznego. Jedyne widoczne efekty tego procesu to nowe (często nieformalne) szlaki - ścieżki turystyczne oraz tereny dużego natężenia ruchu turystycznego, łatwo rozpoznawalne ze względu na obserwowane przekształcenia środowiska przyrodniczego.

Niestety, zazwyczaj są to zjawiska niekorzystne, których przejawem jest wydeptywanie, niszczenie roślinności bądź zaśmiecanie penetrowanych terenów. Czasami procesowi temu towarzyszą podejmowane incydentalnie działania władz i społeczności lokalnych oraz organizacji turystycznych i prośrodowiskowych, zmierzające do usankcjonowania lub przynajmniej uporządkowania tego zjawiska. Zazwyczaj polegają one na uznaniu obszarów za turystyczne i, jeśli funkcja ta nie koliduje z dotychczasowymi sposobami użytkowania gruntów i planami zagospodarowania, doprowadzają do formalnego wyznaczenia rejonów i szlaków, ich oznakowania, utrzymywania porządku, rzadziej trwalszego zagospodarowania turystycznego. Często jednak zdarza się, że nowa funkcja wyraźnie koliduje z dotychczasowym użytkownikiem bądź formą użytkowania. Dzieje się tak zazwyczaj wtedy, gdy zajmowane obszary są własnością prywatną, mają status terenów chronionych lub nowa funkcja nie jest zgodna $\mathrm{z}$ istniejącymi i perspektywicznymi planami zagospodarowania. $W$ takich przypadkach aktywność turystyczna jest ograniczana lub eliminowana $\mathrm{z}$ obszaru, co w konsekwencji prowadzić może do poważnych konfliktów funkcjonalnych (WŁODARCZYK 2009).

Przedstawione działania $w$ większości doprowadzają do wykreowania trzech (najmniej agresywnych dla środowiska przyrodniczego) typów przestrzeni turystycznej. Są to przestrzenie: eksploracji, penetracji, w mniejszym stopniu asymilacji. Efektem jest formalne zaistnienie w przestrzeni geograficznej nowej jakości zróżnicowanej morfologicznie i funkcjonalnie przestrzeni turystycznej (rys. 5).

Ta sama grupa turystów może rozpocząć działalność na badanym obszarze od celowego przekształcania przestrzeni geograficznej, które jest podstawą rozpoczęcia mniej lub bardziej systematycznej aktywności turystycznej. W szczególnych przypadkach rozpoczęcie tego typu działań może być efektem wcześniejszej aktywności o charakterze eksploracyjnym lub penetracyjnym. Tego typu zjawiska prowadzą do przekształceń środowiska geograficznego zazwyczaj w dużo większym stopniu niż opisane wcześniej. Działania podejmowane na tym etapie mają charakter zagospodarowywania 
terenów pod osadnictwo letniskowe (działki i domy letniskowe), a więc bezpośrednio wpływają na kształtowanie przestrzeni kolonizacji turystycznej, bądź są to dodatkowe inwestycje na obszarach skolonizowanych wcześniej, w celu lepszego ich przystosowania do realizacji nowych form aktywności turystycznej. Poza wytyczeniem działek letniskowych pojawiają się równocześnie elementy infrastruktury komunalnej (wodociągi, linie energetyczne, drogi dojazdowe i wewnętrzne itp.), a także stałe obiekty zagospodarowania turystycznego (domy letniskowe, placówki handlowe, gastronomiczne itp.) (WŁODARCZYK 2009).

Celowe przekształcanie przestrzeni geograficznej poprzez różne formy aktywności turystycznej doprowadza do wytworzenia przestrzeni kolonizacji turystycznej, charakteryzującej się większym wewnętrznym zróżnicowaniem morfologicznym i funkcjonalnym. Końcowym etapem przemian związanych z kolonizacją turystyczną może być podprzestrzeń urbanizacji turystycznej (urbanizacji pod wpływem turystyki), która zamyka proces przekształceń przestrzeni geograficznej na potrzeby turystyki (rys. 5).

Tab. 3. Wpływ różnych grup aktorów na typy przestrzeni turystycznej

\begin{tabular}{|c|c|c|c|c|c|c|}
\hline \multirow[b]{2}{*}{$\begin{array}{c}\text { Typ } \\
\text { przestrzeni }\end{array}$} & \multicolumn{6}{|c|}{ Aktorzy przestrzeni turystycznej } \\
\hline & mieszkańcy & organizacje & władze & $\begin{array}{l}\text { przedsię- } \\
\text { biorcy }\end{array}$ & $\begin{array}{c}\text { pracownicy } \\
\text { branży } \\
\text { turystycznej }\end{array}$ & turyści \\
\hline Eksploracji & $\begin{array}{c}\text { niewielki/ } \\
\text { brak }\end{array}$ & $\begin{array}{c}\text { zróżnico- } \\
\text { wany }\end{array}$ & $\begin{array}{c}\text { niewielki/ } \\
\text { brak }\end{array}$ & brak & brak & zasadniczy \\
\hline Penetracji & $\begin{array}{c}\text { zróżnico- } \\
\text { wany, } \\
\text { niewielki - } \\
\text { zasadniczy }\end{array}$ & $\begin{array}{l}\text { zróżnico- } \\
\text { wany }\end{array}$ & $\begin{array}{c}\text { zróżnico- } \\
\text { wany, } \\
\text { niewielki - } \\
\text { zasadniczy }\end{array}$ & $\begin{array}{c}\text { zróżnico- } \\
\text { wany, } \\
\text { niewielki - } \\
\text { zasadniczy }\end{array}$ & $\begin{array}{l}\text { zróżnico- } \\
\text { wany }\end{array}$ & $\begin{array}{c}\text { zróżnico- } \\
\text { wany, } \\
\text { niewielki - } \\
\text { zasadniczy }\end{array}$ \\
\hline Kolonizacji & znaczący & niewielki & znaczący & $\begin{array}{c}\text { zróżnico- } \\
\text { wany, } \\
\text { niewielki - } \\
\text { zasadniczy }\end{array}$ & $\begin{array}{l}\text { zróżnico- } \\
\text { wany }\end{array}$ & znaczący \\
\hline Urbanizacji & $\begin{array}{c}\text { znaczący, } \\
\text { zmniejszający } \\
\text { się } \\
\end{array}$ & niewielki & znaczący & $\begin{array}{c}\text { wyraźnie } \\
\text { zmniejszający } \\
\text { się }\end{array}$ & niewielki & $\begin{array}{c}\text { Znaczący, } \\
\text { zwiększający } \\
\text { się }\end{array}$ \\
\hline Asymilacji & duży & średni & niewielki & $\begin{array}{l}\text { niewielki/ } \\
\text { brak }\end{array}$ & $\begin{array}{l}\text { zróżnico- } \\
\text { wany }\end{array}$ & $\begin{array}{c}\text { zróżnico- } \\
\text { wany, } \\
\text { niewielki - } \\
\text { znaczący }\end{array}$ \\
\hline
\end{tabular}

Źródło: B. WŁODARCZYK (2009) - zmienione. 
Nieco odmiennie przebiega celowe przekształcanie przestrzeni geograficznej na obszarach asymilacji (zazwyczaj są to obszary wiejskie), gdzie podejmowane działania $\mathrm{w}$ znacznym stopniu ograniczane są przez istniejące struktury osadnicze, podział rozłogów itp. Działania obserwowane na tego typu obszarach polegają głównie na adaptacji zabudowy niewykorzystywanej rolniczo (drugie domy) lub wykorzystaniu istniejącej i pełniącej rolnicze funkcje zabudowy zagrodowej na potrzeby turystyki (wsie letniskowe i agroturystyczne) (tab. 3).

\section{Podsumowanie}

Oprócz dziedzictwa oraz infrastruktury przestrzeń turystyczną tworzą ludzie, bez których nie mogłaby ona pełnić swych podstawowych funkcji. Z punktu widzenia człowieka mającego realny wpływ na przestrzeń turystyczną (turystykę w przestrzeni) można zastosować dwa podejścia analityczne. Klasyczne - pokazujące realny wpływ poszczególnych jednostek czy grup na analizowaną przestrzeń poprzez zastosowanie różnego rodzaju miar i wskaźników (można je nazwać podejściem pozytywistycznym), oraz metaforyczne - w przypadku niniejszego opracowaniu częściowo wykorzystujące za E. GOFFMANEM (1981) metaforę sceny, mające bardziej charakter humanistyczny i ponowoczesny. Przeprowadzona analiza potwierdza, że jest to zagadnienie dość złożone, ale przy tym niezwykle ciekawe. Można jednak przyjąć, że:

1. Przestrzeń turystyczna porównana do teatru obejmuje scenę, na której odbywa się spektakl (czytelne są relacje między aktorami oraz scenografią), oraz kulisy dostępne tylko niektórym grupom aktorów (w najmniejszym stopniu turystom).

2. W przestrzeni tej można wyróżnić kilka grup aktorów (mieszkańcy, turyści, pracownicy sektora turystycznego, przedsiębiorcy, organizacje, władze) odgrywających różne lub podobne role.

3. Aktorzy mogą mieć zarówno charakter indywidualny (mieszkańcy, pracownicy, turyści), jak i grupowy (władze, organizacje, przedsiębiorstwa).

4. Wymienione grupy aktorów wchodzą w relacje nie tylko z pozostałymi elementami przestrzeni turystycznej, ale także między sobą, co często decyduje np. o preferowanych kierunkach rozwoju tej przestrzeni. 
5. W zależności od realizowanego scenariusza (strategie, plany rozwoju turystyki) wpływ wymienionych grup aktorów na przestrzeń może być bardzo różny - od braku lub znikomego, po decydujący.

6. Przekształcenia i zmiany $\mathrm{w}$ przestrzeni turystycznej dokonujące się pod wpływem działalności różnych grup aktorów mogą mieć charakter planowy lub żywiołowy, często zależny także od aktualnego stopnia/stadium rozwoju przestrzeni.

\section{Bibliografia}

BAUMAN Z., 1994. Dwa szkice o moralności ponowoczesnej, Biblioteka Kultury Współczesnej, Warszawa, Instytut Kultury, 88 ss.

BEDNAREK-SZCZEPAŃSKA M., 2010, Rola podmiotów lokalnych w rozwoju turystyki wiejskiej na wybranych obszarach Lubelszczyzny, "Studia Obszarów Wiejskich”, XXIII, Komisja Obszarów Wiejskich, Polskie Towarzystwo Geograficzne, Warszawa, 224 ss.

BIRŻAKOW M.B., 2005, Wwiedienije w turizm, Wyd. „Niewskij Fond”, „Izdatielskij Dom Gerda”, Moskwa-Sankt Petersburg, 444 ss.

BoIsSEVAIN J. (red.), 1996, Coping with Tourists. European Reactions to Mass Tourism, "New Directions in Antropology", 1, Berghahn Books, Providence, Oxford, 267 ss.

COHEN E., 1972, Toward a Sociology of International Tourism, „Social Research", 39, 1, s. 164-183.

COHEN E., 1984, The Sociology of Tourism. Approaches, Issues and findings, "Annual Review in Antropology", 10, s. 173-192.

EDENSOR T., 2009, Tourists at the Taj. Performance and Meaning of a Symbolic Site, Routledge, London and New York, 203 ss.

GOFFMAN E., 1981, Człowiek w teatrze życia codziennego, PIW, Warszawa, 328 ss.

GOŁEMBSKI G. (red.), 2002, Metody stymulowania rozwoju turystyki w ujęciu przestrzennym, Wyd. Akademii Ekonomicznej w Poznaniu, Poznań, 316 ss.

Hall M., PAGE S., 2014, The Geography of Tourism and Recreation. Environment, place and space, Routledge, London and New York, 457 ss.

Inny stownik języka polskiego, 2014, M. BAŃKO (red.), wyd. II, t. 1-2, PWN, Warszawa, 2636 ss.

JAFARI J., 1989, Sociocultural Dimension of Tourism. An English Language Literature Review, [w:] Tourism as a Factor of Change, Wiedeń, s. 17-60

JAŁOWIECKI B., 2010, Społeczne wytwarzanie przestrzeni, Wyd. Naukowe Scholar, Warszawa, 326 ss.

KACZMAREK S., KACZMAREK J., 2011, Teoretyczne podstawy nad przestrzenia gościnności, [w:] M. Durydiwka, K. Duda-Gromada K. (red.), Przestrzeń turystyczna - czynniki, różnorodność, zmiany, Uniwersytet Warszawski, Wydział Geografii i Studiów Regionalnych, Warszawa, s. 65-74.

KACZMAREK J., STASIAK A., WŁODARCZYK B., 2010, Produkt turystyczny, Polskie Wyd. Ekonomiczne, Warszawa, 446 ss.

KONIECZNA-DOMAŃSKA A., 1999, Biura podróży na rynku turystycznym, Wyd. Naukowe PWN, WarsZawa, 200 ss.

KOWALCZYK-ANIOE J., 2007, Rozwój przestrzeni urlopowo-wakacyjnej rodzin studentów Uniwersytetu Łódzkiego, ser. „Szlakami Nauki”, 34, Łódzkie Towarzystwo Naukowe, Łódź, 131 ss.

LATOSIŃSKA J., 1998, Przestrzeń urlopowo-wakacyjna pracowników wyższych uczelni Łodzi, ser. „Szlakami Nauki", 27, Łódzkie Towarzystwo Naukowe, Łódź, 159 s.

MACCANNEL D., 2002, Turysta. Nowa teoria klasy próżniaczej, Muza, Warszawa, 315 ss. 
MEAD G.H., 1975, Umyst, osobowość, społeczeństwo, Państwowe Wydawnictwo Naukowe, Warszawa, 533 ss.

MEYER B., 2004, Turystyka jako ekonomiczny czynnik kształtowania przestrzeni, „,Rozprawy i Studia”, 545 (DCXIX), Uniwersytet Szczeciński, Szczecin, 436 ss.

PAWLUSIŃSKI R., 2005, Samorząd lokalny a rozwój turystyki. Przykład gmin Wyżyny Krakowsko-Częstochowskiej, Instytut Geografii i Gospodarki Przestrzennej Uniwersytetu Jagiellońskiego, Kraków, 211 ss.

PODEMSKI K., 2004, Socjologia podróży, Wyd. Naukowe UAM, Poznań, 366 ss.

PRZECŁAWSKI K., 2001, Człowiek a turystyka. Zarys socjologii turystyki, F.H.U., „Albis”, Kraków, 160 ss.

RAPACZ A. (red.), 2001, Przedsiębiorstwo turystyczne w gospodarce rynkowej, Wyd. Akademii Ekonomicznej im. O. Langego we Wrocławiu, Wrocław, 284 ss.

SAGAN I., 2000, Miasto scena konfliktów i wspótpracy. Rozwój miast w świetle koncepcji reżimu miejskiego, Wyd. Uniwersytetu Gdańskiego, Gdańsk, 279 ss.

SHAW G., WILLIAMS A.M., 2004, Tourism and Tourism Spaces, London-New Delhi, 324 ss.

SURDYK-ĆWIKLIŃSKA D., SURDYK A., 2012, Cztowiek jako aktor na scenie życia. Teorie G.H. Meada i E. Goffmana a narracyjne gry fabularne, „Homo Ludens” 1(4), Polskie Towarzystwo Badania Gier, Poznań, s. 45-61.

TUAN Y.F., 1987, Przestrzeń i miejsce, Państwowy Instytut Wydawniczy, Warszawa, 253 ss.

URRY J., 2007, Spojrzenie turysty, Wyd. Naukowe PWN, Warszawa, 279 ss.

URRY J., LARSEN J., 2011, The Tourists Gaze 3.0, SAGE, Los Angeles, London, New Delhi, Singapore, Washington DC, 282 ss.

WINIARSKI R., ZDEBSKI J., 2008, Psychologia turystyki, Wyd. Akademickie i Profesjonalne, Warszawa, 152 ss.

WŁODARCZYK B., 2006, Przestrzeń turystyczna - cykliczność, „aktorzy”, determinanty rozwoju, „Turyzm", 16, 2, s. 41-64.

WŁODARCZYK B., 2009, Przestrzeń turystyczna. Istota, koncepcje, determinanty rozwoju, Wyd. Uniwersytetu Łódzkiego, Łódź, 269 ss.

ZMYŚLONY P., 2008, Partnerstwo i przywództwo w regionie turystycznym, Wyd. Akademii Ekonomicznej w Poznaniu, 155 ss. 